\title{
A PERFORMANCE MANAGEMENT MODEL FOR PHYSICAL ASSET MANAGEMENT
}

\author{
JL Jooste ${ }^{1}$ and DC Page ${ }^{2}$ \\ ${ }^{2}$ Department of Industrial Engineering \\ University of Stellenbosch, South Africa \\ dcp@sun.ac.za
}

\begin{abstract}
There has been an emphasis shift from maintenance management towards asset management, where the focus is on reliable and operational equipment and on effective assets at optimum life-cycle costs. A challenge in the manufacturing industry is to develop an asset performance management model that is integrated with business processes and strategies. The authors developed the $A P M^{2}$ model to satisfy that requirement. The model has a generic reference structure and is supported by operational protocols to assist in operations management. It facilitates performance measurement, business integration and continuous improvement, whilst exposing industry to the latest developments in asset performance management.
\end{abstract}

\section{OPSOMMING}

Daar is ' $\mathrm{n}$ klemverskuiwing vanaf onderhoudsbestuur na batebestuur, waar daar gefokus word op betroubare en operasionele toerusting, asook effektiewe bates teen optimum lewensikluskoste. 'n Uitdaging in die vervaardigingsindustrie is die ontwikkeling van ' $n$ prestasiemodel vir bates, wat geïntegreer is met besigheidsprosesse en -strategieë. Die outeurs het die $A P M^{2}$ model ontwikkel om in hierdie behoefte te voorsien. Die model het ' $n$ generiese verwysingsstruktuur, wat ondersteun word deur operasionele instruksies wat operasionele bestuur bevorder. Dit fasiliteer prestasiebestuur, besigheidsintegrasie en voortdurende verbetering, terwyl dit die industrie ook blootstel aan die nuutste ontwikkelinge in prestasiebestuur van bates.

\footnotetext{
${ }^{1}$ The author was enrolled for the MSc Eng (Industrial Engineering) at the Department of Industrial Engineering, University of Stellenbosch.
} 


\section{INTRODUCTION}

The importance of maintenance management as a contributor to sustainable high performance (i.e. operational efficiency and effectiveness) and profitability have been acknowledged by many researchers (Visser and Pretorius [1], Coetzee, 1998, cited Kutucuoglu et al. [2]). Maintenance management however raises certain questions relating to system design for maintainability, operating procedures for asset performance and the impact on asset life cycle (Campbell [3]). Management's focus has shifted from maintenance management towards total asset management, centering on effective assets at optimum life cycle costs and management of the asset life cycle (including maintenance).

A current problem in the asset management environment is the lack of structured performance management, which is required to effectively control the performance dynamics of the asset and its life cycle; that is caused by:

- Commonly used performance measures, such as availability, reliability, overall equipment effectiveness (Nakajima [4]) and the more recent systems audit approach of Dwight [5] that traditionally came from a maintenance management environment that must be effectively applied within the asset management and life cycle context.

- Financial- and non-financial performance measures (indicators) are required for a balanced view of a company's performance (Kennerley and Neely [6]). Currently financial measures, relating asset performance to the financial statements, are not widely used in either asset- or maintenance management, resulting in an unbalanced view of asset performance.

- The current trend is towards linking all aspects of the organization to ensure balance between strategic goals and operational outcomes (for example, the Balanced Scorecard) (Visser and Pretorius [1], De Waal [7], Chang and Morgan [8], Kaplan and Norton [9]). Currently there is limited integration between asset management and the organizational functions and hierarchies; which needs to be addressed before assets can be effectively managed.

Consequently these shortcomings lead to ineffective and under-performing assets with high life cycle costs, which have a negative influence on the financial performance and return on capital investment.

To address these needs, it may be argued that a performance management model for asset management is required. Such a model would incorporate research and developments in the field of performance management whilst recognising existing asset management practices.

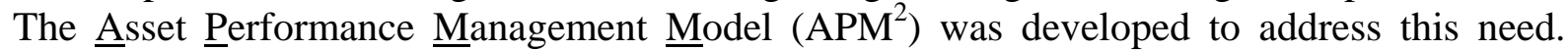
Current research, based on the last two decades' developments in performance management, together with the experience of a leading asset management consultancy formed the foundation of the conceptual framework of the model. Four features characterize the APM ${ }^{2}$; (i) it gives a balanced (financial- and non-financial) view of asset performance, (ii) it links asset performance to strategic business objectives, (iii) it facilitates decision-making and problem solving at different managerial levels, and (iv) it enhances asset control and continuous improvement. 
In the following paragraphs we discuss the principles of performance and asset management and the research and development process followed, with specific reference to development of a performance framework and to performance measurement. The development of an Asset Performance Management Model $\left(\mathrm{APM}^{2}\right)$ is discussed and operational support dockets - a set of protocols assisting with the management of operations - are then presented. Finally, conclusions are drawn.

\section{PRINCIPLES OF PERFORMANCE AND ASSET MANAGEMENT}

Performance management is a topical subject in business and the past decade has seen a significant number of publications on performance related issues, such as performance frameworks, operational efficiency and performance integration. Performance can be seen as a collection of processes that will assist stakeholders in taking appropriate actions to create a performing organization in the future (i.e. more efficient and effective) (Lebas and Euske [10]). To take such actions, decisions must be based on information from quantitative indices. This process of measuring and collecting performance data, interpretation, identifying problems and making decisions to improve performance within the scope of the business goals, have been associated with the term performance management (Kaydos [11]). Industry has become obsessed with performance, attempting to quantify every aspect of a business (Neely and Austin [12]), whilst not focusing on the "critical few" processes that do need to be managed.

Although companies have always managed their assets, (Woodhouse [13]) asset management is becoming increasingly important. In today's competitive business environment it is prerequisite to manage assets effectively and efficiently in order to get maximum return on investment. This can only be achieved by considering the entire life cycle of the asset (Figure 1) together with all related costs. Therefore, the days of thinking in 'functional silos', by seeing maintenance management and asset management as separate issues, are over (Campbell [3], Woodhouse [14]).

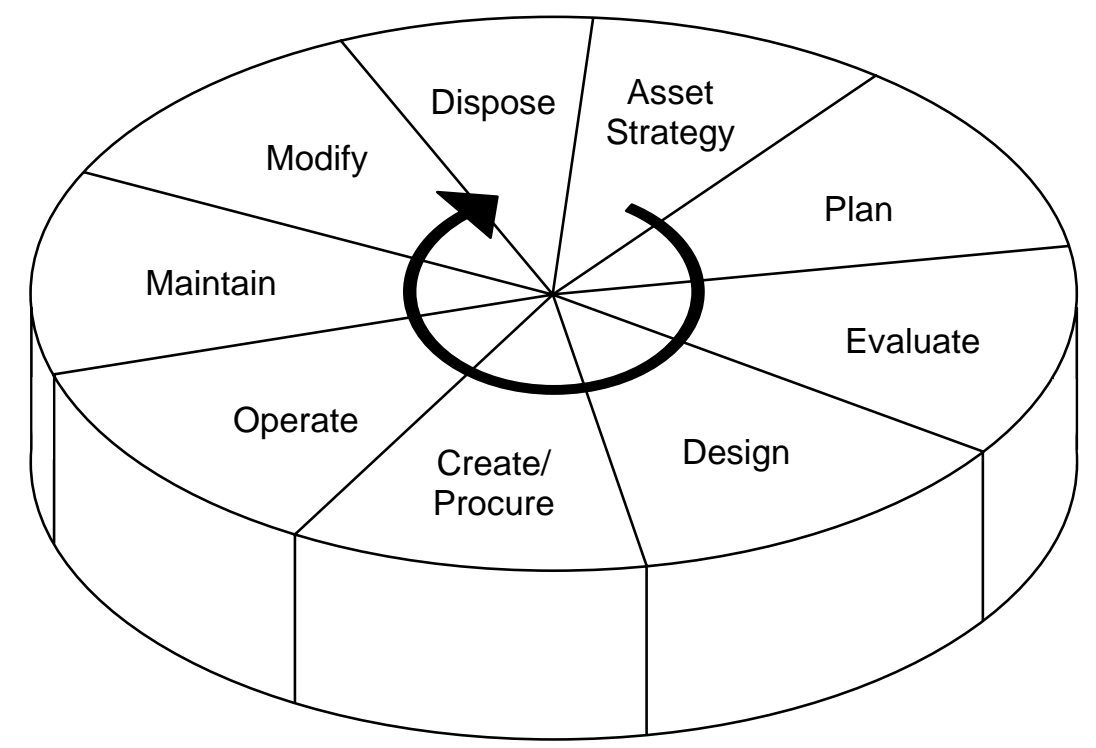

Figure 1: Asset Life Cycle (Source: Campbell [3]) 
A general description for asset management is the global management process through which the highest value decisions regarding the use and care of assets are made and executed (Petersen [15]). In conjunction with the asset life cycle, and acknowledged by authors (for example, Woodhouse [13]), it is clear that asset management affects all areas of the business. Therefore it needs to be aligned and integrated into functional and operational business processes.

The relationship between asset management and structured performance management was identified through systems thinking philosophies such as Total Productive Maintenance (Yoshida [16]) and reliability models (Kolarik [17]). In the current business environment a mere relationship proves to be inadequate. Modern performance practices promote the vertical integration between top-level goals and operational strategies as well as horizontal integration between process results and customers' requirements. These practices need to be applied to asset management explaining the need for synergy between asset- and performance management that can be incorporated within business processes.

\section{RESEARCH AND DEVELOPMENT PROCESS}

Recent studies cited by Kennerley and Neely [6] highlighted that effective performance management is characterized by a "critical few" components (building blocks). These components are based on the last two decades' developments in the field of performance management and include aspects of understandibility, balanced performance measurement and functional- and hierarchical integration. Combined with the limitations that have been identified within asset performance, we have identified five building blocks for an asset performance management model have been identified. These include:

- a performance framework based on a proven structure, commonly recognized in industry.

- recent developments and features in performance management that need to characterize the model.

- a range of non-financial performance measures/indicators that must be objective and preferably ratio-based, as well as

- a range of financial performance measures/indicators - also objective and ratio-based, and

- a structure that can relate asset performance to organizational and operational hierarchies.

These building blocks were researched for the newest developments after which the best concepts were evaluated and selected for the model. Each of the building blocks is discussed separately:

\subsection{Performance Framework}

Performance frameworks and design processes published between 1977 and 2001 were evaluated $^{3}$. Bititci's Integrated Performance Measurement System (IPMS) was identified as

\footnotetext{
${ }^{3}$ These include; Du Pont Pyramid (Chandler, 1977, cited Neely et al. [18]), Performance Measurement Matrix (Keegan et al., 1989, cited Neely et al. [18]), Performance Measurement Questionnaire (Dixon et al., 1990, cited Neely et al. [18]), SMART (Cross and Lynch, 1991, cited Neely et al. [18]), Results and Determinants Framework (Fitzgerald et al., 1991, cited Neely et al. [18]), Balanced Scorecard (Kaplan and Norton, [9]), Inputs, Processes, Outputs and Outcomes Framework (Brown, 1996, cited Neely et al. [18]), Tableau de Bord (Epstein and Manzoni, 1997, cited Kennerley and Neely [6]), Integrated Performance Measurement System
} 
the optimum concept to underpin and support the work. Selection was based on the following criteria:

- The IPMS has the ability to integrate performance management into an organization's business structure.

- It includes the most recent work in the field of performance framework research and development, and

- Its modularity allows it to be easily and effectively used as a foundation to incorporate other asset performance building blocks of the business processes of the organization.

Bititci's objective for the Integrated Performance Measurement System (IPMS) was to establish an auditable reference model or tool that could be used to audit and improve organizations' performance measurement models. The IPMS reference structure was built according to (i) the Viable Systems Model (Beer, 1985, cited Bititci et al. [20]), (ii) the CIMOSA business process architecture (ESPRIT Consortium AMICE, 1991, cited Bititci et

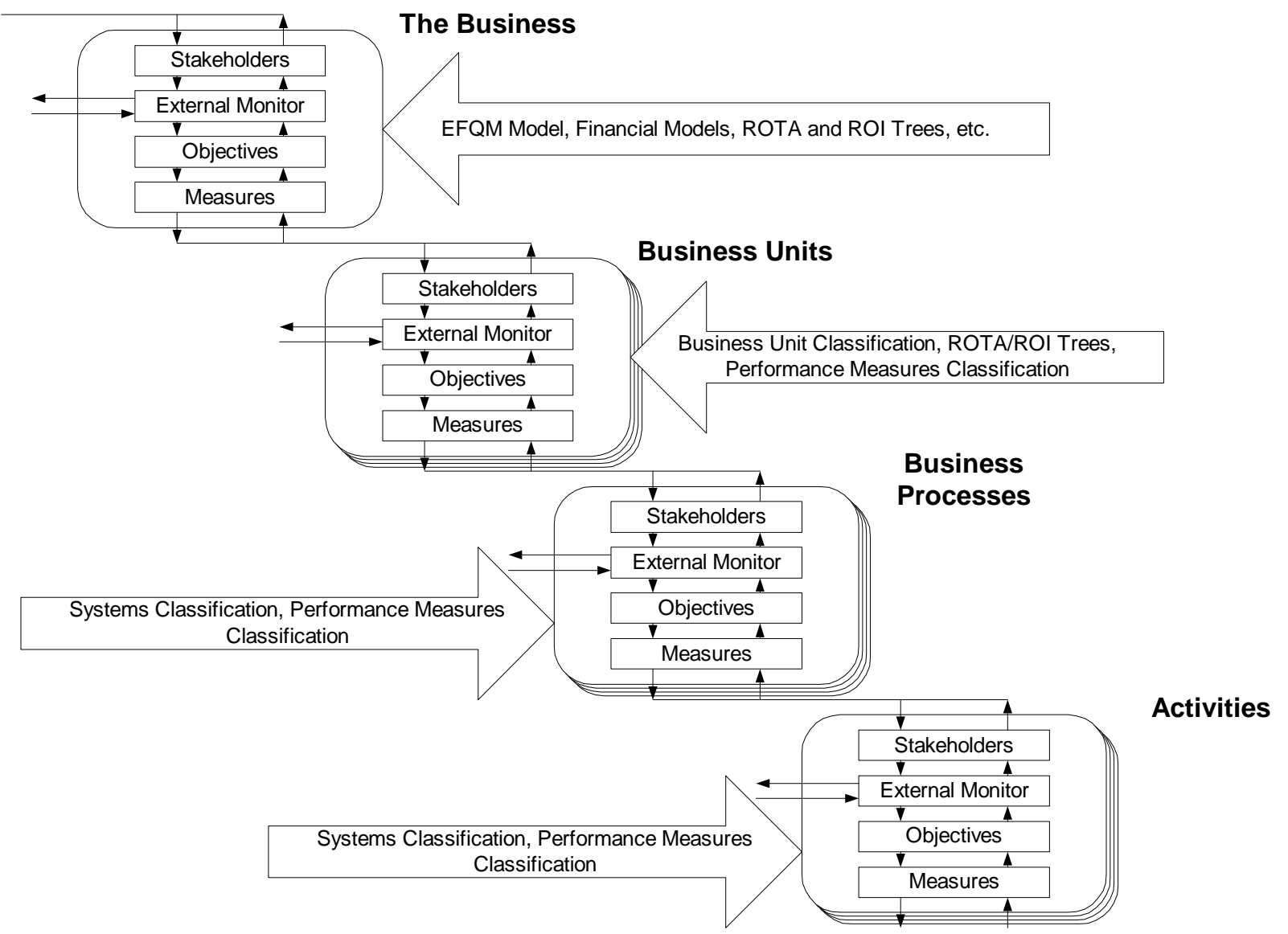

Figure 2: IPMS Reference Structure (Source: Bititci et al. [19])

- The Business - representing the entire organization, which exists for a purpose.

(Bititci et al. [19]), Chang and Morgan’s Performance Scorecard (Chang and Morgan [8]), Performance Prism (Neely and Adams, 2001, cited Kennerley and Neely [6]), Quality Function Deployment (Kutucuoglu et al. [2]), Performance Measurement for World Class Manufacturing (Maskell, 1989, cited Neely et al. [18]), Performance Criteria System (Globerson, 1996, cited Neely et al. [18]), Cambridge Performance Measurement Design Process (Neely et al., 1996, cited Neely et al. [18]). 
al. [20]), and (iii) concepts of policy deployment (Bititci et al. [19]). The IPMS reference structure is presented in Figure 2 and includes four levels:

- The Business Units - to fulfill the purpose the business operates various business units each servicing a particular market.

- The Business Processes - to service the demand each business unit controls various operating processes, which are supported by various support processes.

- The Activities - each business process operates a series of activities to fulfill its purpose.

At each level of the reference structure four elements (Figure 2) are considered. These elements are used to manage performance, and include:

- Stakeholder Requirements - set direction by recognizing and understanding the requirements of its stakeholders.

- External Monitor - monitor external environment with respect to stakeholders' requirements, benchmarked with competitors and world-class performance.

- Objectives - set and deploy internal objectives based on the implications and criticality of the developmental gaps together with appropriate targets and time scales.

- Performance Measures - coordinate sub-systems by monitoring, reviewing, and reporting on the objectives.

The last element represents the link to the next level in the reference structure.

\subsection{Performance Features}

The criteria and characteristics within the foregoing frameworks and design processes, were collectively evaluated and the features identified that were common to a comprehensive performance framework/process. The features may be categorized in two groups, namely: characteristics and parameters. Characteristics are features designed into the model, by which the end result will be characterized; and include the following:

- Understandable - terminology must be clear, while metrics should be easy to use to encourage understanding and ownership.

- Practical - data collection and calculations must be clearly defined and should be applicable.

- Vertical Integration - criteria and measures should be connected to business strategies.

- Horizontal Integration - stakeholder requirements should be connected to process results.

- Proactive Management - proactive management must be promoted and facilitated.

- Strategic Development - performance criteria must facilitate and provide input for strategy development.

Parameters are decision variables that are embedded in the model and are used to manage performance. Parameters can be customized, without changing the model structure, and will be different for various applications. The following parameters are included:

- Stakeholder Participation - performance criteria should be selected through discussions with immediate stakeholders. 
- External Comparison - performance outcomes must enable comparison between similar, but independent businesses.

- Feedback - confenient and simple feedback on measures and progress should be communicated to applicable employees, with demonstrable trends, where possible.

A special feature is measures (indicators), which can be seen as a parameter that is dynamically managed, and has the following characteristics:

- Financial- and non-financial measures - both financial- and non-financial measures should be included.

- Leading (i.e. operational) and lagging (i.e. financial) measures - to provide data for monitoring past performance and data for planning future performance.

- Objectivity - the use of accurate, quantitative measurements, rather than qualitative measurements based on human perception.

- Ratio-based measures - rather than absolute numbers.

- Differentiation - between control and improvement measures.

- Unit specific - measures should be organizational-unit specific.

- Unit control - measures should be under the control and monitoring of the evaluated organizational unit.

- Stimulate Improvement - measures should stimulate continuous improvement rather than merely monitoring performance.

\subsection{Non-financial Performance Measures/Indicators}

The selected two non-financial performance measures are Overall Equipment Effectiveness (OEE) and Overall Plant Performance (OPP). The selection was based on (i) the measures' validity in industry, (ii) understandability to all asset management stakeholders and (iii) the ease of integration of the measures' subordinate ratios over the organizational and operational hierarchies.

OEE is a shop floor improvement tool addressing how effective factories run their processes when scheduled to run:

$$
\text { OEE = Availability } \times \text { Performance } \times \text { Quality }
$$

OPP includes utilization of total time. It gives an indication of asset performance relative to each minute of the clock (operation time and authorized downtime) and not only operating time (actual operation time exclusive of authorized downtime). It creates a means by which decision makers can be held accountable for strategic and policy decisions concerning asset management. Thereby OPP can be seen as a comprehensive measure giving an overall performance indication of the capital invested or shareholder's investment (excl. management and decision-makers).

$$
\begin{aligned}
O P P & =\text { Utilization } \times \text { Availability } \times \text { Performance } \times \text { Quality } \\
& =\text { Utilization } \times \text { OEE }
\end{aligned}
$$


The combination of non-financial performance measures is presented in equations (1) to (6) (Nakajima [4], Hansen [21], and PRAGMA Products [22]) and is supported by Figure $3^{4}$.

$$
\text { Utilization }=\frac{\text { Loading Time }}{\text { Total Time }}=\frac{B}{A} \text {, }
$$

$$
\text { where Loading Time }=\text { Total Time }- \text { Authorized Downtime }
$$

$$
\begin{aligned}
\text { Availability } & =\frac{\text { Loading Time }-\left(\text { Unauthorized Downtime }+ \text { DeviationTime }{ }_{M}{ }^{\{5\}}\right)}{\text { Loading Time }}=\frac{C}{B} \\
\text { Performance } & =\frac{\text { Actual Production } \times \text { Theoretical Cycle Time }}{\text { Operating Time }} \\
& =\frac{\text { Actual Production }}{\text { Operating Time } \times \text { Standard Speed }},
\end{aligned}
$$

where Operating Time $=$ Loading Time - Unauthorized Downtime $+{\text { Deviation } \text { Time }_{P}\{5\}}^{\{}$

$$
\begin{aligned}
& \text { Quality }=\frac{\text { Good Production }}{\text { Actual Production }}=\frac{E}{D}, \\
& \text { where Good Production }=\text { Gross Production }- \text { Startup Defects }- \text { Quality Defects } \\
& \begin{array}{l}
\text { OEE }=\text { Availability } \times \text { Performance } \times \text { Quality } \\
O P P=\text { Utilization } \times \text { Availability } \times \text { Performance } \times \text { Quality }
\end{array}
\end{aligned}
$$

\subsection{Financial Performance Measures/Indicators}

Financial performance measures in the asset management environment are not widely used. Despite this, a range of financial considerations and indicators have been identified to measure performance. This also assists in decision-making within the asset life cycle. The selected measures are Return on Total Assets (ROTA), opportunity costs, alternative comparison and replacement analysis.

ROTA is calculated as a percentage and represents the operating efficiency and productivity of an enterprise and is independent of how a company is financed. OEE is a driver for ROTA, which is also a driver for Return on Equity (ROE). It is calculated as follows (Walsh [23]):

\footnotetext{
${ }^{4}$ The term "time" indicates duration, i.e. 3 hours, and not an instant during the flow of time, i.e. 15:00.

${ }^{5}$ Deviation time is a variation on Nakajima's original calculations. Authorized downtime is a result of decisions and policies, while unauthorized downtime occurs due to technical, operational and/or quality deficiencies during production. Deviation time is however different since it is a result of human inefficiency. Availability and Performance are therefore negatively influenced, while operating time is reduced. An example concerned with production is when lunch is authorised for $30 \mathrm{~min}$ and the operator takes a $40 \mathrm{~min}$ lunch, $10 \mathrm{~min}$ is deviation time for which the operator (production) needs to be held accountable. Similarly an example concerned with maintenance is when preventive maintenance is scheduled for $1 \mathrm{hr}$ but maintenance takes $1 \frac{1}{2}$ hrs then $1 / 2 \mathrm{hr}$ is deviation time for which the artisans/technicians (maintenance) need to be held accountable. In equation (2) and (3) provision is made for Production Deviation Time (Deviation Time P $_{\text {) }}$ and Maintenance Deviation Time (Deviation Time ${ }_{M}$ ) where it is categorised, in order to truthfully hold the various functions accountable for their actions.
} 


$$
\text { ROTA }=\frac{\text { Earnings Before Interest } \& \text { Tax }}{\text { Total Assets }}
$$

ROTA is a key tool in decision-making and benchmarking with the advantage that it can be broken into subsidiary ratios that can be measured at different levels:

$$
\begin{aligned}
\text { ROTA } & =\text { Profit Margin } \times \text { Asset Turn } \\
& =\left(\frac{\text { Earnings Before Interest } \& \text { Tax }}{\text { Sales }}\right) \times \frac{\text { Sales }}{\text { Total Assets }}
\end{aligned}
$$

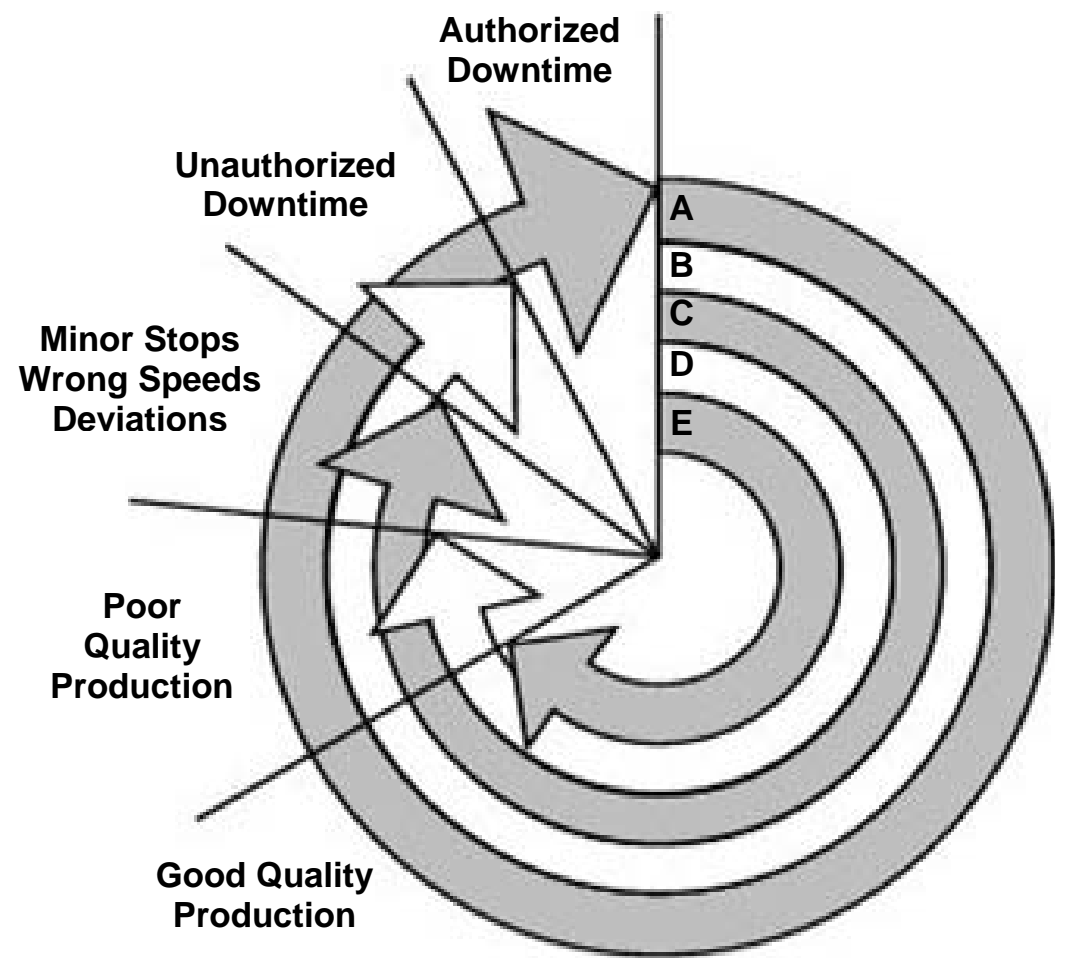

Figure 3: OEE \& OPP Wheel (Source: PRAGMA Products [22])

Profit margin is a well-known measure of a company's profitability. Asset turn, conversely, is underrated, but gives an important view on the total sales achieved by the company in relation to total assets. The drivers for the profit margin are the cost items in the profit-andloss statement, whilst for asset turn it is each asset type in the balance sheet. Equation (7c) can therefore be expanded to accommodate different cost items and asset types:

$$
\text { ROTA }=\left(1-\sum_{i} \frac{C_{i}}{\text { Sales }}\right) \times\left[\sum_{j}\left(\frac{\text { Sales }}{A_{j}}\right)^{-1}\right]^{-1}
$$




$$
=\left(\frac{\text { Sales }-\sum_{i} C_{i}}{\sum_{j} A_{j}}\right),
$$

where $C_{i}$ is cost item $i$ in the collection of expenses, before tax and interest deductions, in the profit-and-loss statement and where $A_{j}$ is the value of asset type $j$ in the collection of total assets in the balance sheet.

Opportunity cost from an asset management perspective is the monetary value of the lost capacity due to under-performing assets or questionable policy decisions. By expressing OEE and OPP in units transferred (Hansen [21]) it is possible to calculate the opportunity costs. Opportunity costs calculated from OEE (OC $\mathrm{OEE}_{\mathrm{OE}}$ ) monitors asset practices, while the respective Opportunity cost for OPP (OC $\mathrm{OPP})$ monitors policy decisions. $\mathrm{OC}_{\mathrm{OEE}}$ and $\mathrm{OC}_{\mathrm{OPP}}$ are calculated as follows:

$$
\begin{aligned}
\text { OC }_{\text {OEE }} & =(\text { Theoretical Units in Loading Time }- \text { Sellable Units }) \times \text { Unit Price } \\
& =\left(\frac{\text { SellableUnits }}{\text { OEE }}-\text { Sellable Units }\right) \times \text { Unit Price }
\end{aligned}
$$

From a traditional perspective $\mathrm{OC}_{\mathrm{OEE}}$ would be an efficiency. For consistency it is considered as an Opportunity Cost in the asset management context.

$$
\begin{aligned}
O C_{O P P} & =(\text { Theoretical Units in Total Time }- \text { Sellable Units }) \times \text { Unit Price } \\
& =\left(\frac{\text { SellableUnits }}{\text { OPP }}-\text { Sellable Units }\right) \times \text { Unit Price }
\end{aligned}
$$

During the planning stages of the asset life cycle it is important to determine whether the procurement of the asset is a viable option from an investment perspective and which alternative offers the most benefit. The choice between alternatives must incorporate the fundamental purpose of capital investment, namely to obtain at least the minimum attractive rate of return (MARR) for each monetary unit invested (Sullivan et al. [24]). There are various methods of comparison but, for this application, alternatives are compared according to net cash flows with the Present Worth method. For each alternative the Present Worth is calculated (Sullivan et al. [24]):

$$
P W(i)=-P+\sum_{j}^{N} \frac{R_{j}}{(1+i)^{j}}+F(1+i)^{-N},
$$

where PW = Present Worth, $\mathrm{P}=$ Capital investment, $\mathrm{R}_{j}=$ Annual revenues less costs in year $j, \mathrm{~F}=$ Salvage/disposal value (if any), $i=$ Minimum attractive rate of return (MARR) and $\mathrm{N}=$ Period.

It is prerequisite for the $\mathrm{PW}$ to be greater than 0 at $i=$ MARR, after which the alternative with the largest PW value is the preferred option.

Similarly, during the asset lifetime decisions will have to be made whether assets should be retired from use, continued in service or replaced by a new asset - the so-called 'replacement 
problem'. The similarity between the evaluation of alternatives and comparison between a current and a new asset requires no further discussion.

\subsection{Asset Object System}

An asset object system is used to relate asset management to the rest of the organization. The asset object system was refined with deference to the work on multi-functional integration of maintenance by Riis et al. [25]. Refinements to the original maintenance object system include additional management levels to provide for different operational and managerial requirements. Figure 4 illustrates the refined asset object system, which integrates the enterprise's asset management, namely operational and organizational systems.

Provision was made for organizational hierarchy sub-levels between the enterprise and factory (additional management levels), and the factory level and the process units (additional operational levels). This in-built logic would accommodate regional, national as well as international management levels between senior management and the factory, whilst larger enterprises with more complex operations might require additional operations management levels. The asset object system is therefore the foundation for integrating asset management with the organizational and operational hierarchies.

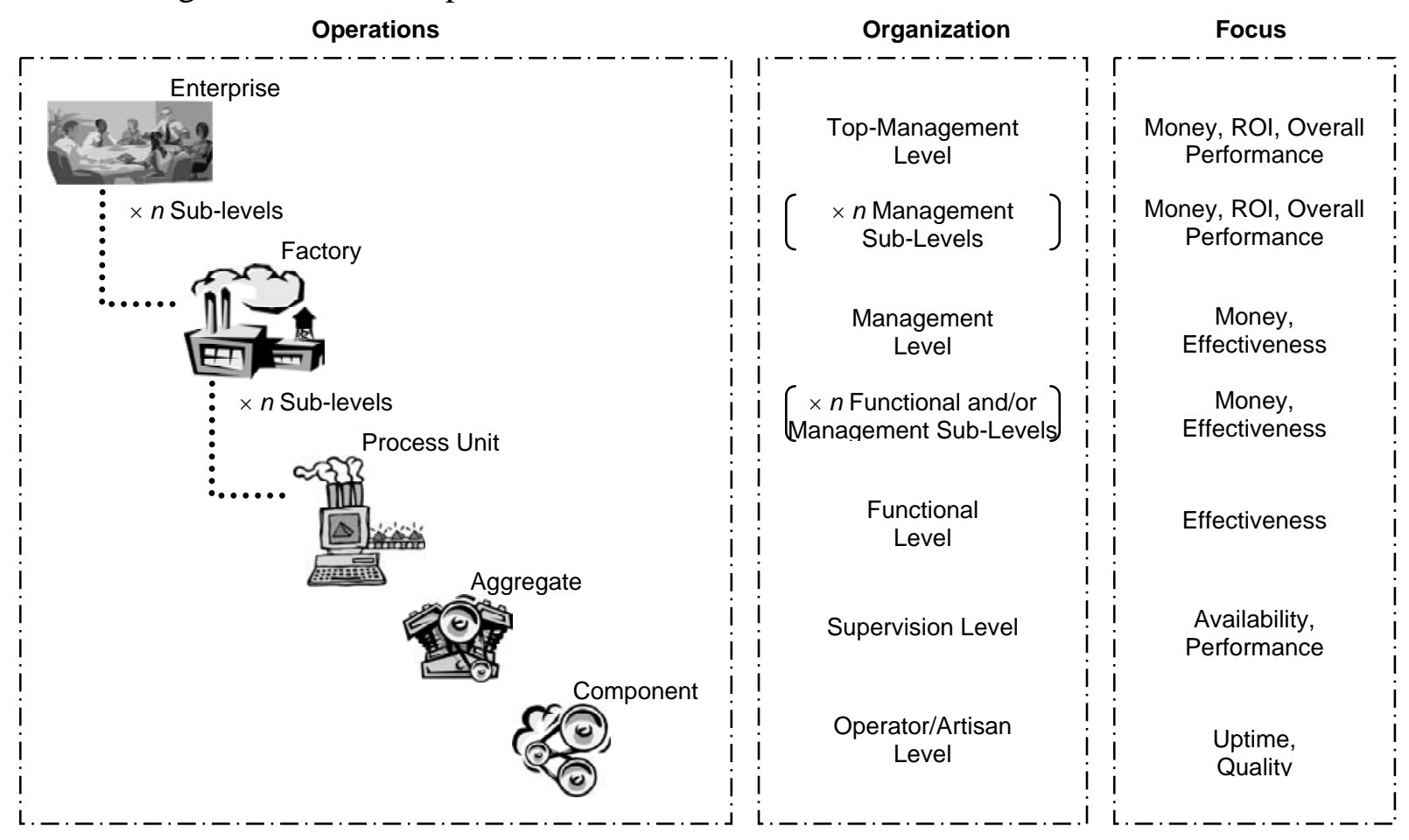

Figure 4: Asset Object System (Source: Derived from Riis et al. [25])

\section{ASSET PERFORMANCE MANAGEMENT MODEL (APM $\left.{ }^{2}\right)$}

The $\underline{\text { Asset }}$ Performance $\underline{\text { Management }}$ Model $\left(\mathrm{APM}^{2}\right)$ was developed, through the integration of the five building blocks and with assistance from an industrial partner [26]. $\mathrm{APM}^{2}$ is a functional and utilitarian asset performance management model that (i) gives a balanced view of financial- and non-financial asset performance, (ii) links asset performance and operational 
outcomes to strategic goals, (iii) facilitates decision-making on different managerial and operational levels, and (iv) enhances asset control and continuous improvement. The APM ${ }^{2}$ consists of two components, namely:

- The APM Reference Structure, and

- a range of APM Dockets.

\subsection{APM Reference Structure}

The APM Reference Structure (APMRS) is developed by integrating two building blocks the framework and the asset object system. Bititci's IPMS (Figure 2) is modified according to the management levels of the asset object system, which results in a reference structure that encompasses all control levels of asset management. Industries with larger operations and management hierarchies are also accommodated. The APM Reference Structure can therefore be described as a basic structure that provides guidance and control, that gives perspective on the entire model and explains the high-level content of the model. The final APMRS, illustrated in Figure 5, consists of five levels each with a distinct management focus:

- Level 1: Enterprise

The enterprise level represents the entire organization, which oversees the high-level performance of assets and focuses on return on investment and overall performance.

- Level 2: Factory

The factory level represents the production units of the enterprise that need to manage their assets effectively to drive overall performance and return on investment.

- Level 3: Process Unit

The process unit level represents the various functional units within the factory. These units must ensure effective provision, operation and care of assets to drive overall equipment effectiveness and plant performance.

- Level 4: Aggregate

The aggregate level represents process sub-units that manage aggregates of assets and ensure optimum availability, performance and quality.

\section{- Level 5: Component}

The component level represents the low-level assets, consisting of machines and/or production lines that need to be managed to ensure optimum uptime and quality.

\subsection{APM Dockets}

The APM Dockets are a subset of the reference structure and realizes the integration of the remaining three building blocks - performance features, financial and non-financial measures with the $\mathrm{APM}^{2}$. Each of the reference structure levels (levels 1 to 5) has an APM Docket. These dockets are two to three page documents identifying activities that will guide the stakeholders of different management units towards improved asset performance. The dockets can be regarded as the detailed design of the reference structure. From Figure 5, each of the five levels consists of six similar elements (corresponding to the parameter part of the 


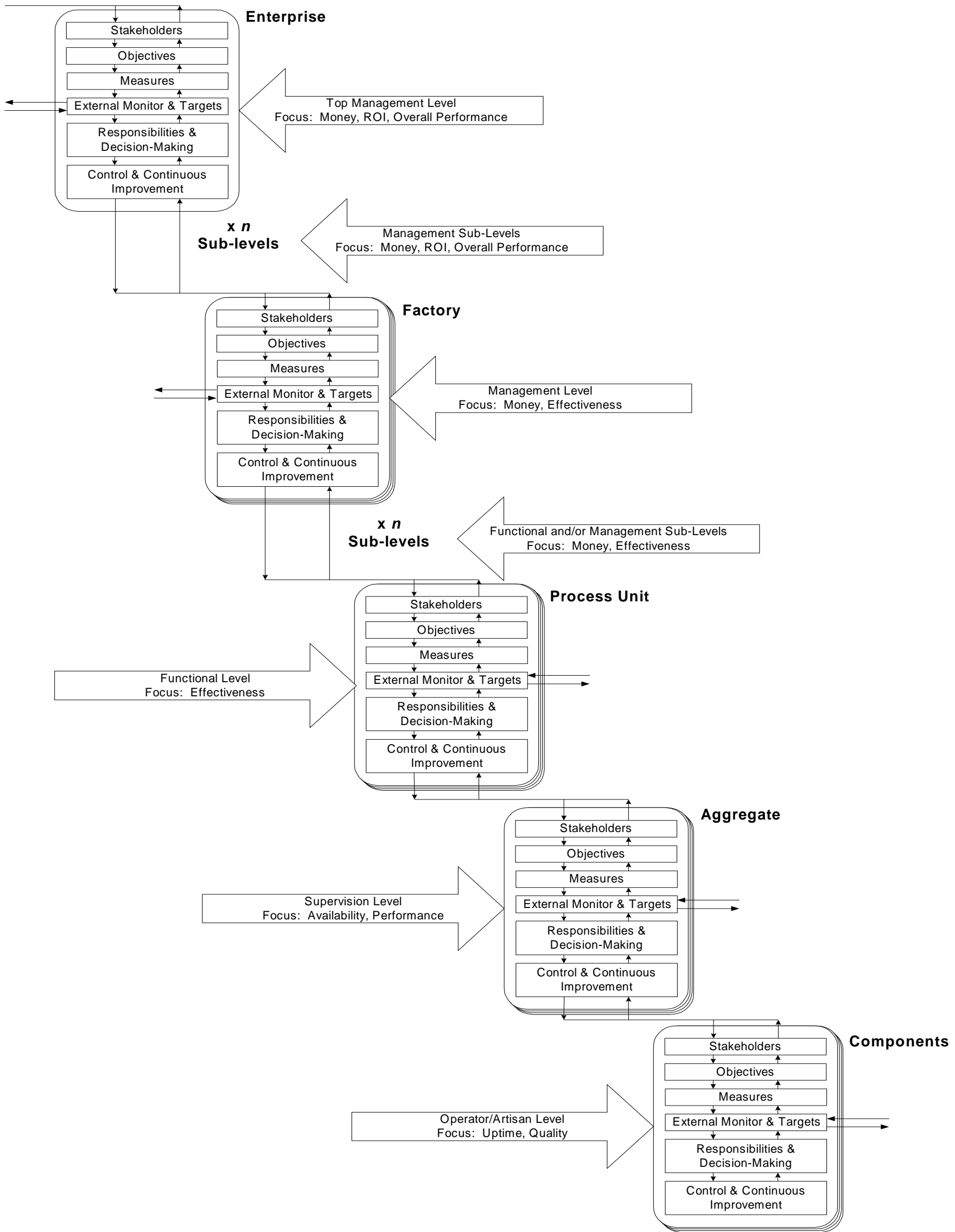

Figure 5: APM Reference Structure 
performance features building block). These elements form the foundation for each APM Docket. Although each docket is unit-specifically designed, elements of all levels are interrelated forming an integrated asset management chain (refer to the example of an APM Factory Docket discussed later). Each of the APM Dockets is designed according to the elements:

\section{- Element 1: Stakeholders}

The stakeholders, who are responsible for the management of the specific level, are identified. Stakeholders can be classified as interested or affected. Interested stakeholders control the specific APM Dockets, whereas affected stakeholders play a supportive role. Table 1 illustrates possible stakeholders for the different levels of the APM Reference Structure.

\begin{tabular}{|l|l|}
\hline APMRS Levels & \multicolumn{1}{|c|}{ Possible Stakeholders } \\
\hline Enterprise & Top Management \\
\hline Factory & Factory Management \\
\hline Process Units & $\begin{array}{l}\text { Production Manager } \\
\text { Maintenance Manager }\end{array}$ \\
\hline Aggregates & $\begin{array}{l}\text { Production Supervisor } \\
\text { Maintenance Supervisor }\end{array}$ \\
\hline Components & $\begin{array}{l}\text { Operator } \\
\text { Artisan/Technician }\end{array}$ \\
\hline
\end{tabular}

Table 1: List of Stakeholders

- Element 2: Objectives

For each level the internal objectives need to be set and deployed. The objectives include the vision, job descriptions of the respective stakeholders' and the performance requirements that need to be achieved. Research by Visser and Pretorius [1] emphasizes issues, such as strategies, vision, mission and goals, confirming this element's importance as part of asset performance management.

\section{- Element 3: Measures}

The $\mathrm{APM}^{2}$ encompasses a balanced range of financial and non-financial performance measures, and this element realizes the integration of these with the model. Each of these measures is broken into various subordinate ratios that are level-specifically controlled. In Figure 6 a relationship tree of the high-level breakdown of the measures is illustrated, while Table 2 lists these together with the corresponding stakeholders who will control the respective measures (reference to the equation numbers are given in brackets).

\section{- Element 4: External Monitor and Targets}

For each of the unit-specific measures, internal as well as externally benchmarked targets need to be set on a periodic basis. Although limited information based on best practice benchmarks (Mitchell [27]) and world-class standards (Le Plastrier [28]) is available it is problematic to find external targets that truly represent the best-in-class performance of a specific industry. However if asset performance is done in collaboration with asset management advisors, they should be able to provide reliable information. 


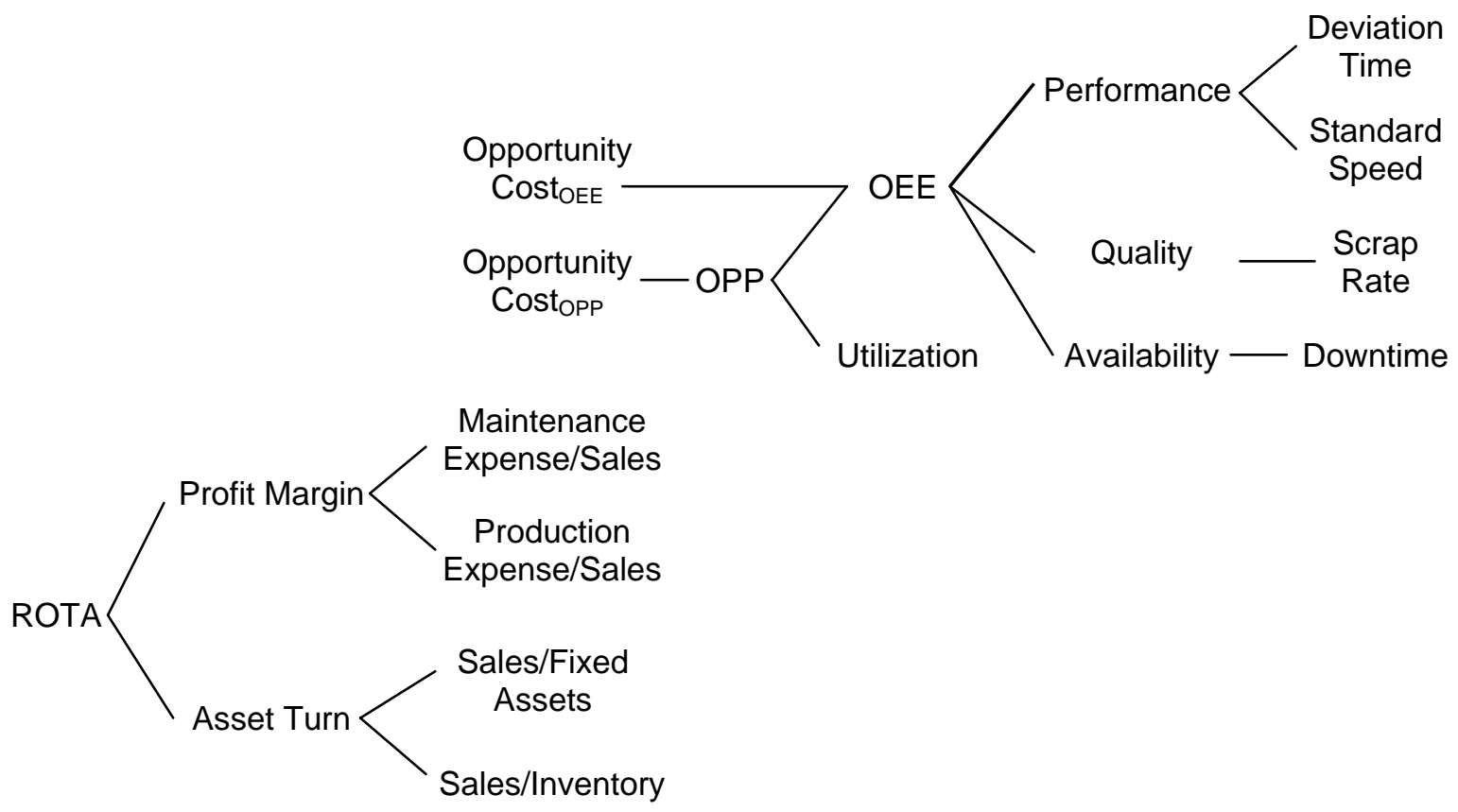

Figure 6: Factory Docket Performance Measures

\section{- Element 5: Responsibilities and Decision-Making}

For each stakeholder a list of responsibilities needs to be identified. These are periodic asset related activities to effectively ensure optimum asset performance. Also for each stakeholder a decision tree needs to be developed assisting in systematic and analytical decision-making.

\section{- Element 6: Control and Continuous Improvement}

For each level control, continuous improvement procedures should be identified and deployed. Actions taken during asset management conduct needs to be transparent to stakeholders through communicative feedback, while metrics, deviations from targets and new targets need to be discussed at periodic review sessions. For continuous improvement, various sets of improvement practices required to grow asset management maturity - the level of competence - need to be identified. These sets of practices need to be implemented on a periodic basis (i.e. week, month, quarter) by the respective stakeholders; there upon it is incorporated within the stakeholders' list of responsibilities.

- Element 7 represents the link to the next level in the APM Reference Structure.

$\mathrm{APM}^{2}$ is a functional, non-complex structure, which is logical to understand, with the dockets realizing practical implementation. The model has a strong theoretical foundation, has generic application, and can be used in a wide range of manufacturing industries. The APM Reference Structure rationalizes the model components, while the APM Dockets can be used to develop a tailored set of management documents to reflect an organization's specific asset performance management needs. 


\begin{tabular}{|c|c|c|c|c|c|c|c|c|c|}
\hline \multirow[b]{2}{*}{ Measures } & \multirow{2}{*}{ 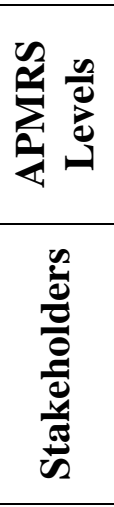 } & \multirow{2}{*}{ 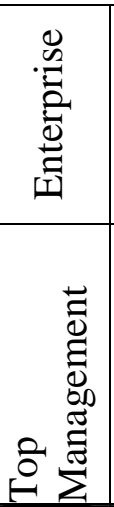 } & \multirow{2}{*}{ 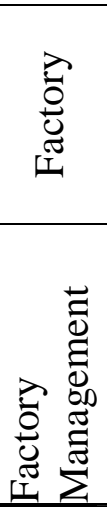 } & \multicolumn{2}{|c|}{ 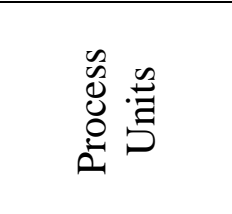 } & \multicolumn{2}{|c|}{ 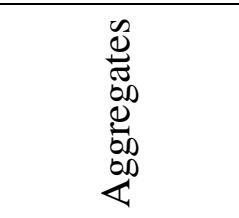 } & \multicolumn{2}{|c|}{ 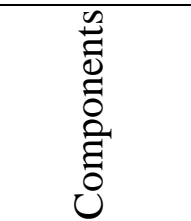 } \\
\hline & & & & 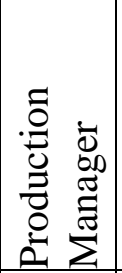 & 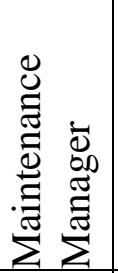 & 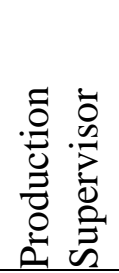 & 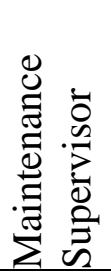 & $\begin{array}{l}\tilde{0} \\
\frac{\pi}{0} \\
0 \\
0\end{array}$ & 胥 \\
\hline OPP & $(6)$ & & & & & & & & \\
\hline Utilization & (1) & & & & & & & & \\
\hline OEE & (5) & & & & & & & & \\
\hline Availability & (2) & & & & & & & & \\
\hline Performance & (3) & & & & & & & & \\
\hline Quality & (4) & & & & & & & & \\
\hline Unauthorized Downtime & $(2)$ & & & & & & & & \\
\hline Scrap Rate & (4) & & & & & & & & \\
\hline${\text { Deviation } \text { Time }_{M}}$ & $(2)$ & & & & & & & & \\
\hline Standard Speed & (3b) & & & & & & & & \\
\hline Deviation Time $_{\mathrm{P}}$ & $(3)$ & & & & & & & & \\
\hline ROTA & (7a) & & & & & & & & \\
\hline Opportunity Cost ${ }_{\mathrm{OPP}}$ & $(9)$ & & & & & & & & \\
\hline Opportunity Cost OEE $_{\text {O }}$ & (8) & & & & & & & & \\
\hline Profit Margin & (7b) & & & & & & & & \\
\hline Asset Turn & (7b) & & & & & & & & \\
\hline $\begin{array}{l}\text { Maintenance } \\
\text { Expenses/Sales }\end{array}$ & $(7 d)$ & & & & & & & & \\
\hline Labour/Sales & (7d) & & & & & & & & \\
\hline Material/Sales & (7d) & & & & & & & & \\
\hline Sales/Inventory & (7d) & & & & & & & & \\
\hline
\end{tabular}

Table 2: Performance Measures related to Stakeholders

\subsection{Example of an APM Factory Docket}

An APM Docket is a documented procedure that is used by the stakeholders to control asset performance at a specific management level or control level (refer to the levels of the APMRS). To illustrate the use of the APM Dockets an example of a Factory Docket is described.

\section{Stakeholders (Element 1)}

The interested and affected stakeholders for the Factory Docket are marked as shown in Figure 7. 


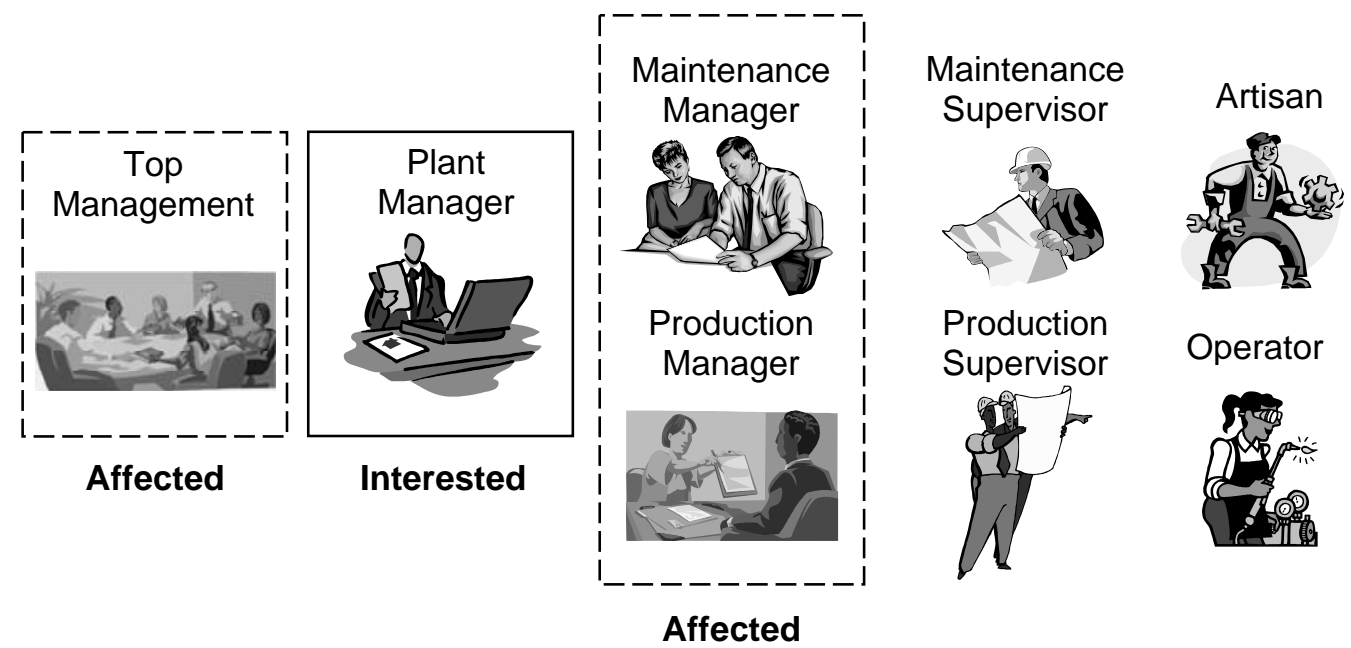

Figure 7: Factory Docket Stakeholders

Objectives (Element 2)

- Vision

*Insert company/department’s vision.

- Job Description

To productively manage the entire factory and all of its business units of which asset management is a part.

- Performance Requirements

- Improving overall plant performance (OPP) through monitoring and managing of OEE and utilization.

- Managing financial implications of assets as well as return on investment drivers, such as profit margin and asset turn concerned with asset performance management.

- Strategically plan asset management considerations and activities.

- Support and lead subordinates to improved asset performance.

\section{Measures (Element 3)}

The measures applicable to the Factory Docket are circled as shown in Figure 8.

External Monitor \& Targets (Element 4)

Performance targets for the Factory Docket are entered in Table 3.

Responsibilities \& Decision-Making (Element 5)

- Responsibilities

The responsibilities for the Factory Docket are shown in Table 4. 


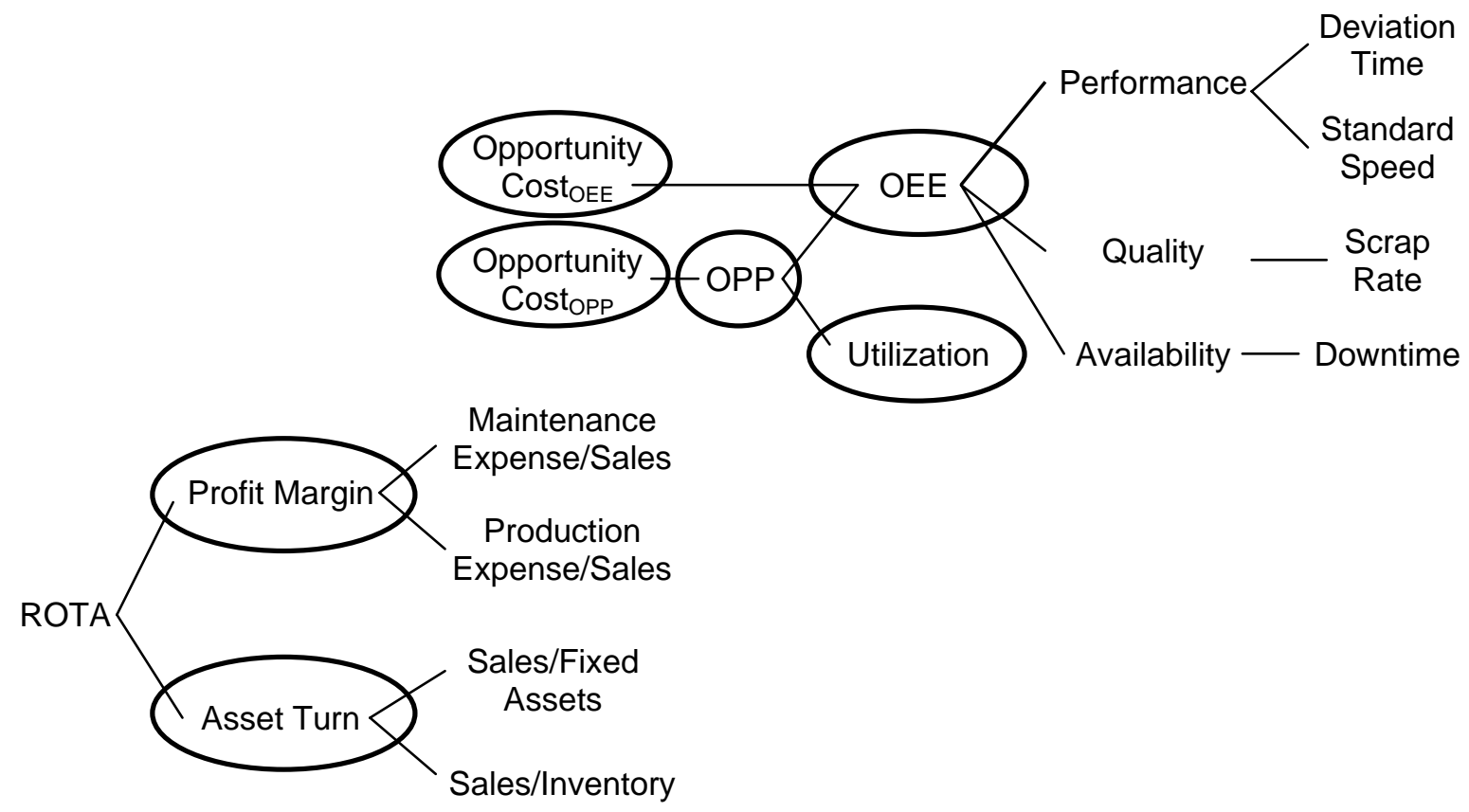

Figure 8: Factory Docket Performance Measures

\begin{tabular}{|l|c|l|l|l|}
\cline { 2 - 5 } \multicolumn{1}{c|}{} & $\begin{array}{c}\text { Industry } \\
\text { Leader }\end{array}$ & Week & Month & Quarter \\
\hline OEE & & & & \\
\hline Opportunity Cost & & & & \\
\hline OPP & & & & \\
\hline Utilization & & & & \\
\hline Opportunity Cost & & & & \\
\hline Profit Margin & & & & \\
\hline Asset Turn & & & & \\
\hline
\end{tabular}

Table 3: Factory Docket Performance Targets

\begin{tabular}{|c|l|}
\hline Daily & $\begin{array}{l}\text { Monitor and control OEE, OPP and the associated opportunity costs, to } \\
\text { ensure optimum overall performance. }\end{array}$ \\
\hline Weekly & Monitor and control the profit margin and asset turn ratios. \\
\hline \multirow{3}{*}{ Monthly } & $\begin{array}{l}\text { Develop and delegate medium- to long-term maintenance and work } \\
\text { strategies. }\end{array}$ \\
\cline { 2 - 2 } & $\begin{array}{l}\text { Drive asset management improvement program by motivating, } \\
\text { encouraging and supporting managers, through leadership. }\end{array}$ \\
\hline $\begin{array}{c}\text { Before/during } \\
\text { asset strategy } \\
\text { decisions }\end{array}$ & $\begin{array}{l}\text { Conduct alternative comparison and replacement analysis in relation to } \\
\text { new and current asset strategies. }\end{array}$ \\
\hline
\end{tabular}

- Decision-making

Table 4: Factory Docket Responsibilities

The decision tree for the Factory Docket is shown in Figure 9. 


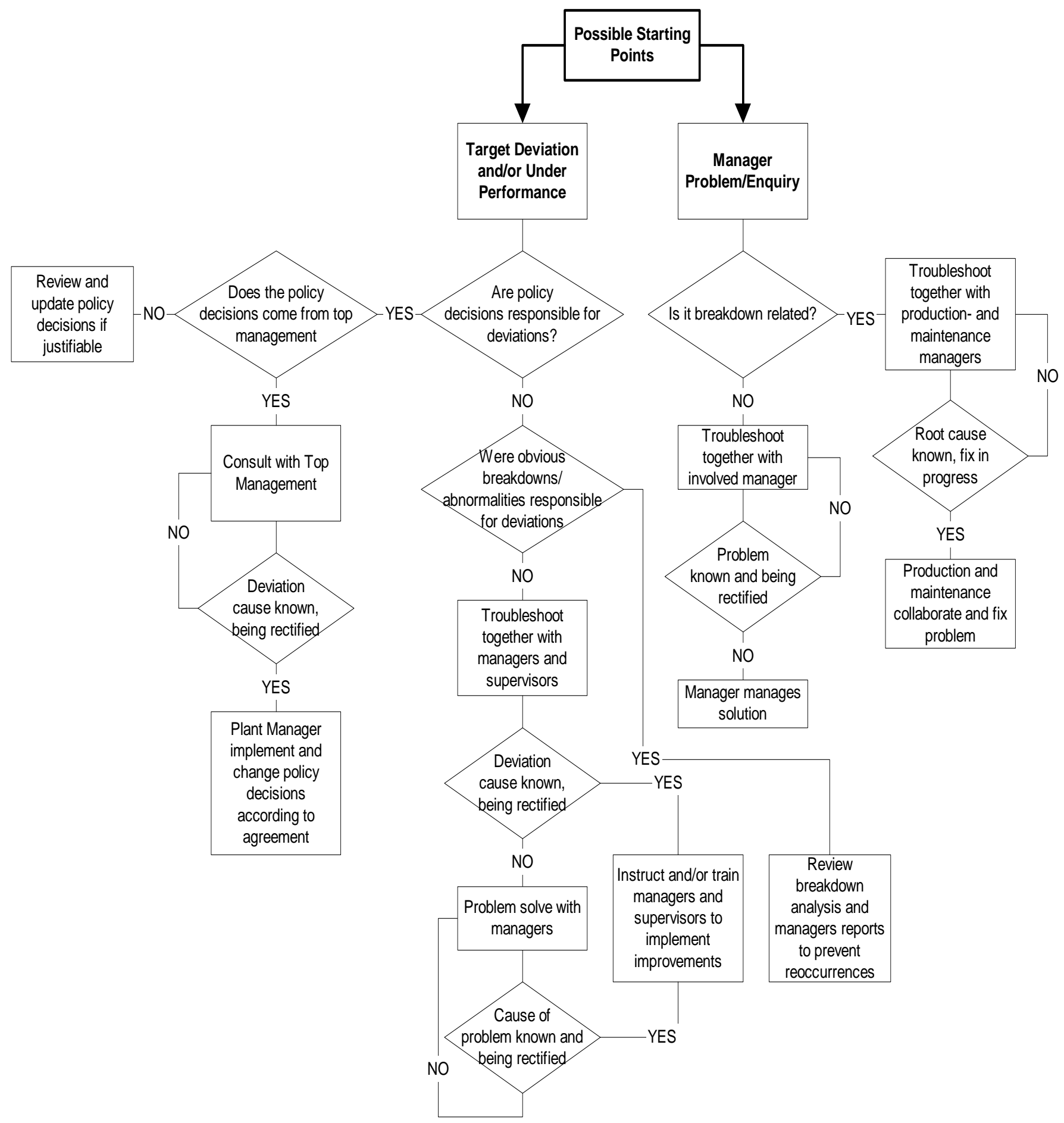

Figure 9: Factory Docket Decision Tree

\section{Control \& Continuous Improvement (Element 6)}

- Feedback

The feedback requirements for the Factory Docket are listed in Table 5. 
- Review

- Facilitate review meetings with managers where (i) high-level measures are discussed, (ii) variations/deviations from the targets are justified, and (iii) periodic (month, quarter) goals and new targets are set.

- Review the factory levels' measures periodically (month, quarter, bi-annual) with top management and discuss problems, policy decisions, improvements and new targets.

\section{- Improvement Practices}

Improvement Practices are plant specific and need to be identified in accordance with each factory's asset management maturity. In the case of the Factory Docket, key performance areas for improvement practices might include the following:

- Strategic Management

- Organization \& Manpower

- Financial Management

- $\quad$ Asset Acquisition \& Disposal

\begin{tabular}{|c|l|}
\hline Monthly & $\begin{array}{l}\text { Review and give feedback to managers about breakdown analysis-, } \\
\text { inspection- and FMECA reports. }\end{array}$ \\
\hline Quarterly & $\begin{array}{l}\text { Give progress feedback to top management concerning the asset } \\
\text { management program of the specific factory. }\end{array}$ \\
\hline $\begin{array}{c}\text { If policy } \\
\text { decisions are } \\
\text { updated }\end{array}$ & $\begin{array}{l}\text { Give feedback to production- and maintenance managers concerning } \\
\text { policy decisions and strategic goals coming from top management. }\end{array}$ \\
\hline
\end{tabular}

Table 5: Factory Docket Feedback

\section{CONCLUSIONS}

The development of the $\mathrm{APM}^{2}$ contributes to the knowledge of Asset Management by assisting companies with improvement of asset performance management, and thereby improving effectiveness and productivity. The model is a tool that can be applied to overcome issues that industry experiences in asset performance management, such as the lack of balanced performance measures. The model is characterized by a systematic and structured approach that (i) is applicable to the asset management and life cycle cost context, that (ii) gives a balanced view on performance measurement, that (iii) integrates strategic and operational aspects of the business, and that (iv) facilitates proactive management and continuous improvement. Each of these characteristics contributes to improvement of a company’s asset management.

$\mathrm{APM}^{2}$ also exposes industry to the latest developments in asset performance management. The insight and experience of the industrial partner were invaluable in this regard. Practitioner input, in the form of proven practices, allowed an insightful foundation for the $\mathrm{APM}^{2}$. The underlying theoretical underpinning to the model incorporating the latest research in asset and performance management supports the notion that this work has made an invaluable contribution to the knowledge base on Asset Performance Management. 
$\mathrm{APM}^{2}$ is a generic framework that satisfies all the requirements (i.e. features, measures) identified during the research and development process. It consists of five-levels: the APM Reference Structure - which can be modified according to the size and asset management structure of a user company. While the APM Reference Structure is used to guide asset performance from a management perspective, with each of its levels having an APM Docket. These dockets consist of activities that need to be executed in order to manage assets. Whilst the basic activities are generic, customization of the dockets will be required to effectively manage and improve asset management maturity.

Arguably, a shortcoming of the work is that the $\mathrm{APM}^{2}$ has not yet been validated in practice as part of an asset management program. The industrial partner [26] with whom the model was developed, however, plans on integrating the $\mathrm{APM}^{2}$ with its asset management program. Through this application the model will be validated in practice in the near future. Additionally, the $\mathrm{APM}^{2}$ does not make provision for resource constraints. It is assumed that manpower and spare parts are always available, which is idealistic due to the dynamics of everyday business operations. The $\mathrm{APM}^{2}$ handles periods in which resources are not available as 'downtime'. It does not, however, specify how the downtime needs to be categorised - it will either be authorised downtime, holding the decision-makers responsible or unauthorised downtime holding the maintenance function responsible. Each company using the $\mathrm{APM}^{2}$ will need to decide on a policy of how to specify downtime in the case of resources not being available.

\section{REFERENCES}

[1] Visser, J.K. and Pretorius, M.W. (2003), "The development of a Performance Measurement System for Maintenance”, South African Journal of Industrial Engineering, 14(1), pp. 83-97.

[2] Kutucuoglu, K.Y., Hamali, J., Irani, Z. and Sharp, J.M. (2001), “A framework for managing maintenance using performance measurement systems”, International Journal of Operations \& Production Management, 21(1/2), pp. 173-194.

[3] Campbell, J.D. (1995), Uptime: Strategies for Excellence in Maintenance Management, Productivity Press, Portland, Oregon.

[4] Nakajima, S. (1988), Introduction to TPM: Total Productive Maintenance, Productivity Press, Cambridge, MA.

[5] Dwight, R. (1999). “Searching for real maintenance performance measures”, Journal of Quality in Maintenance Engineering, 5(3), pp. 258-275.

[6] Kennerley, M. and Neely, A. (2002), "Performance measurement frameworks: A review", in Neely, A, (Ed.), Business Performance Measurement: Theory \& Practice. Cambridge University Press, Cambridge, UK, pp. 145-155.

[7] De Waal, A.A. (2002). “The power of world-class performance management: Use it!”, Measuring Business Excellence, 6(3), pp. 9-19.

[8] Chang, R.Y. and Morgan, M.W. (2000). Performance Scorecards: Measuring the Right Things in the Real World, Jossey-Bass Inc., San Francisco.

[9] Kaplan, R.S., and Norton, D.P. (1996). Translating Strategy into Action: The Balanced Scorecard, Harvard Business School Press, Boston.

[10] Lebas, M. and Euske, K. (2002), "A conceptual and operational delineation of performance”, in Neely, A, (Ed.), Business Performance Measurement: Theory \& Practice. Cambridge University Press, Cambridge, UK, pp. 65-79. 
[11] Kaydos, W. (1991), Measuring, Managing, and Maximizing Performance. Productivity Press, Cambridge, MA.

[12] Neely, A. and Austin, R. (2002). "Measuring performance: The operations perspective", in Neely, A, (Ed.), Business Performance Measurement: Theory \& Practice. Cambridge University Press, Cambridge, UK, pp. 41-50.

[13] Woodhouse, J. (2001), “Asset Management”, Woodhouse Partnership Ltd. Available http://www.twpl.co.uk/

[14] Woodhouse, J. (2001), “Asset Management Decision-Making”, Woodhouse Partnership Ltd. Available http://www.plant-maintenance.com/articles/

[15] Petersen, S.B. (2002), “Defining Asset Management”, Strategic Asset Management White Papers. Available http://www.samicorp.com/PublicationsPages/Articles/

[16] Yoshida, K., Hongo, E., Kimura, Y., Ueno, Y., Mitome, Y., Kaneda, S. and Morimoto, T., (1990), Training for TPM: A manufacturing success story. Productivity Press, Cambridge, MA.

[17] Kolarik, W.J., (1995), Creating Quality: Concepts, Systems, Strategy and Tools. McGraw Hill, Singapore.

[18] Neely, A., Mills, J., Platts, K., Richards, H., Gregory, M., Bourne, M., and Kennerley, M. (2000). "Performance measurement system design: developing and testing a process-based approach”, International Journal of Operations \& Production Management, 20(10), pp. 1119-1145.

[19] Bititci, U., Carrie, A., and Turner, T. (2002), "Integrated Performance Measurement Systems: Structure and Dynamics in Neely, A, (Ed.), Business Performance Measurement: Theory \& Practice. Cambridge University Press, Cambridge, UK, pp. 174-196.

[20] Bititci, U.S., Turner, T., and Begemann, C. (2000) "Dynamics of Performance Measurement Systems", International Journal of Operations and Production Management, 20(6), pp. 692-704.

[21] Hansen R.C. (2001), Overall Equipment Effectiveness: A powerful production/maintenance tool for increased profits. Industrial Press, New York.

[22] PRAGMA Products, (2003), ON KEY APMS: Performance Measuring Training. PRAGMA Products, Cape Town.

[23] Walsh, C. (1996), Key Management Ratios: How to analyze, compare and control the figures that drive company value. Pitman Publishing, London.

[24] Sullivan, W.G., Bontadelli, J.A. and Wicks, E.M. (2000), Engineering Economy. Prentice-Hall, New Jersey.

[25] Riis, J.O., Luxhøj, J.T. and Thorsteinsson, U. (1997). “A situational maintenance model”, International Journal of Quality \& Reliability Management, 14(4), pp.349-366.

[26] URL: www.pragma.co.za

[27] Mitchell, J.S. (2002). Excerpt from Physical Asset Management Handbook. [online]. Houston: Clarion Technical Publishers. Available from: http://www.reliabilityweb.com/excerpts/excerpts/pam.htm [17 November 2003]

[28] Le Plastrier, M. (2003). "Facing the music of reality in production", South African Instrumentation \& Control, 19(10), pp. 62-63. 